\title{
ANALISIS PELAKSANAAN PEMBELAJARAN JARAK JAUH DI SD NEGERI KARANGRENA 03
}

\author{
Kurnia Dwi Setyaningsih', Karma Iswasta Eka², Badarudin ${ }^{3}$ \\ ${ }^{123}$ Elementary School Teacher Education Study Program \\ Universtas Muhammadiyah Purwokerto \\ E-mail: ${ }^{1}$ kurniadwi1999@gmail.com¹, 2eka2001id@gmail.com², \\ 3badarudinbdg@gmail.com³
}

\begin{abstract}
This study aims to analyze and describe the implementation of distance learning, as well as determine the supporting and inhibiting factors for the implementation of distance learning at SDN Karangrena 03. This type of research is qualitative research with descriptive methods. Participants in this study were the principal, teachers, and parents or guardians of students. Data were collected by means of observation, interviews and documentation. The results of this study are described as follows: 1) Distance learning at SDN Karangrena 03 is carried out using online and offline methods, the strategy adopted by the teacher is to use technology with PJJ media via Whatsapp group. 2) Supporting factors for the implementation of distance learning, namely teachers prepare careful planning in implementing PJJ, the support of internet facilities from schools, and teachers and parents can use technology for communication without any time constraints. The inhibiting factor for the implementation of distance learning is that most parents cannot always assist students in learning because they have jobs that cannot be left behind, assignments given by the teacher require more explanation, and students' learning motivation decreases.
\end{abstract}

Key words: Distance learning, Support, Barrier

\begin{abstract}
Abstrak. Penelitian ini bertujuan untuk menganalisis dan mendeskripsikan pelaksanaan pembelajaran jarak jauh, serta mengetahui faktor pendukung dan penghambat pelaksanaan pembelajaran jarak jauh di SDN Karangrena 03. Jenis penelitian yang digunakan adalah penelitian kualitatif dengan metode deskriptif. Partisipan dalam penelitian ini yaitu kepala sekolah, guru, dan orang tua atau wali murid. Pengambilan data dilakukan dengan cara observasi, wawancara dan dokumentasi. Hasil penelitian ini dijelaskan sebagai berikut: 1) Pembelajaran jarak jauh di SDN Karangrena 03 dilaksanakan menggunakan metode daring dan luring, strategi yang diterapkan oleh guru yaitu menggunakan teknologi dengan media PJJ melalui Whatsapp group. 2) Faktor pendukung pelaksanaan pembelajaran jarak jauh yaitu guru mempersiapkan perencanaan yang matang dalam melaksanakan PJJ, adanya dukungan fasilitas internet dari sekolah, dan guru serta orang tua dapat memanfaatkan teknologi untuk komunikasi tanpa adanya kendala waktu. Faktor penghambat pelaksanaan pembelajaran jarak jauh yaitu sebagian besar orang tua tidak bisa selalu mendampingi peserta didik dalam belajar karena memiliki pekerjaan yang tidak bisa ditinggalkan, tugas
\end{abstract}




\section{JRPD (Jurnal Riset Pendidikan Dasar)}

Jurnal Riset

Pendidikan Dasar

yang diberikan guru memerlukan penjelasan lebih, dan motivasi belajar peserta didik menjadi menurun.

Kata Kunci: Pembelajaran jarak jauh, Pendukung, Penghambat

\section{PENDAHULUAN}

Kurikulum yang diterapkan pada pendidikan di Indonesia saat ini adalah kurikulum 2013 yang merupakan salah satu elemen dari standar proses yang mengalami perubahan guna mencapai keberhasilan pembelajaran dan pembentukan kompetensi peserta didik. Konsep kurikulum berkembang sejalan dengan perkembangan teori dan praktik pendidikan. Era sekarang perkembangan dunia pendidikan dan teknologi menuntut terciptanya sumber daya manusia yang berkualitas, oleh karena itu diperlukan pembangunan pendidikan sebagai sarana dan wacana dalam membina sumber daya manusia. Prioritas utama untuk menciptakan sumber daya manusia yang dapat menjunjung tinggi bangsa Indonesia adalah pendidikan.

Pendidikan di Indonesia saat ini sedang menghadapi masalah, karena pada awal tahun 2020 keadaan dunia sangat memprihatinkan dengan adanya pandemi Covid-19. Setiawan (2020: 29) menyatakan bahwa Covid-19 merupakan penyakit menular yang disebabkan oleh sindrom pernapasan akut coronavirus 2 (severe acute respiratory syndrome coronavirus 2 atau $S A R S-C o V-2)$. Virus ini merupakan keluarga besar coronavirus yang dapat menyerang hewan. Ketika menyerang manusia, coronavirus biasanya menyebabkan penyakit infeksi saluran pernafasan, seperti flu, MERS (Middle East Respiratory Syndrome), dan SARS (Severe Acute Respiratory Syndrome). Covid-19 seringkali menular pada manusia tanpa adanya gejala sehingga membahayakan orang-orang di sekitarnya. Covid-19 tidak hanya menyerang Indonesia bahkan seluruh dunia, oleh karena itu pemerintah menerapkan PSBB atau yang disebut dengan Pembatasan Sosial Berskala Besar dengan tujuan untuk mencegah penyebaran Covid-19.

Pembatasan tersebut salah satunya berdampak pada penutupan sekolah yang menyebabkan peserta didik harus belajar dari rumah. Hal tersebut sependapat dengan Latip (2020: 107) yang menyatakan bahwa pandemi Covid-19 berpengaruh besar terhadap berbagai sektor, termasuk sektor pendidikan. Semua sekolah dan perguruan tinggi hampir di semua negara yang terdampak Covid-19 memberlakukan kebijkan pembelajaran dari rumah atau pembelajaran jarak jauh (PJJ). Semua sekolah pada situasi seperti ini tidak dapat melaksanakan pembelajaran secara langsung atau tatap muka, maka harus melaksanakan pembelajaran jarak jauh atau disebut dengan PJJ.

Pelaksanaan PJJ dpat membantu agar pendidikan dapat terus berjalan pada situasi dan kondisi seperti ini. Setiawan (2020: 30) menyatakan bahwa pembelajaran jarak jauh merupakan pembelajaran ketika peserta didik dan pengajar tidak selalu hadir secara fisik yang bersamaan di sekolah. Pelaksanaan dapat sepenuhnya jarak jauh (hybrid) atau campuran jarak jauh dengan kelas 
(blended). Yerusalem (2015: 481) juga berpendapat bahwa PJJ memungkinkan untuk melakukan pembelajaran secara jarak jauh tanpa terikat jarak, di manapun dan kapanpun dapat mengakses pembelajaran tersebut.

Pembelajaran jarak jauh merupakan sistem pembelajaran yang tidak berlangsung dalam satu ruangan dan tidak ada interaksi tatap muka secara langsung antara pengajar dan pembelajar. Daryanto (2017: 96) menyatakan bahwa PJJ merupakan pembelajaran dengan menggunakan suatu media yang memungkinkan terjadinya interaksi antara pengajar dan pembelajar yang tidak bertatap muka secara langsung, dengan kata lain melalui PJJ dimungkinkan antara pengajar dan pembelajar berbeda tempat bahkan bisa dipisahkan oleh jarak yang sangat jauh sehingga memudahkan proses pembelajaran. Teguh (2015: 9) berpendapat bahwa pembelajaran jarak jauh atau dalam kasus ini dikenal juga dengan e-learning merupakan sebuah metode pembelajaran baru yang menggunakan teknologi informasi dan komunikasi sebagai alat utamanya untuk menyampaikan materi dan strategi pembelajaran.

Strategi pembelajaran yang dipilih dalam PJJ menurut Kemendikbud No.4 tahun 2020 yang menyatakan dapat dilakukan melalui beberapa tahap. Pendataan alat teknologi menjadi pilihan strategi pertama yang perlu diprioritaskan, karena teknologi menjadi sarana atau alat yang menghubungkan konten materi yang disampaikan guru kepada peserta didik. Metode yang digunakan dalam kegiatan belajar dari rumah menurut SE Dinas Pendidikan dan Kebudayaan Kabupaten Cilacap (2020) menyatakan bahwa dilaksanakan menggunakan PJJ yang dibagi ke dalam dua pendekatan: 1) PJJ dalam jaringan (daring), 2) PJJ luar jaringan (luring). Pelaksanaan PJJ, satuan pendidikan dapat memilih pendekatan (daring atau luring atau kombinasi keduanya) sesuai dengan ketersediaan dan kesiapan sarana dan prasarana.

Model pembelajaran era digital saat ini memiliki perbedaan dibandingkan dengan model pembelajaran konvensional. Model PJJ menurut Azis (2019: 309) menyatakan bahwa model pembelajaran era digital terdiri 3 model yang pertama, guru memberikan materi pembelajaran secara online pada peserta didik kemudian di download dan dipelajari secara manual (offline), kedua guru memberikan materi pembelajaran secara online dan peserta didik mempelajari secara online juga, dan ketiga kolaborasi antara pembelajaran yang berlangsung antara online dengan offline. Pembelajaran yang sudah dilakukan akan berakhir dengan kegiatan evaluasi baik penilaian ulangan harian, penilaian tengah semester ataupun penilaian akhir semester.

Penilaian Akhir Tahun (PAT) oleh pendidik dilaksanakan mengacu kepada Surat Edaran Kementerian Pendidikan Nomor 4 Tahun 2020, dan Surat Edaran Kepala Dinas Pendidikan dan Kebudayaan Kabupaten Cilacap Nomor 443.1/1482/02/15. Nilai Akhir Tahun (Kenaikan Kelas) pada jenjang SD diperoleh dari rata-rata nilai ulangan/ Penilaian Tengah Semester Terakhir (semester genap), ditambah nilai penilaian harian yang dilakukan dalam bentuk 


\section{JRPD (Jurnal Riset Pendidikan Dasar)}

Jurnal Riset

portofolio yang diperoleh sebelumnya, penugasan, tes daring, dan bentuk asesmen jarak jauh lainnya. Pembobotan diserahkan pada satuan pendidikan. Pelaksanaan PJJ tentu saja membutuhkan sumber dan media sebagai pendukung dalam proses pembelajaran.

Sumber dan media pendukung PJJ dilihat sesuai dengan pendekatan yang digunakan dalam melaksanakan PJJ. Sumber dan media yang mendukung PJJ secara daring menurut Kemendikbud (2020: 2) yang menyatakan bahwa dapat menggunakan gawai (gadget) maupun laptop melalui beberapa portal dan aplikasi pembelajaran daring. Media pembelajaran daring yang direkomendasikan oleh Kemendikbud antara lain yaitu, rumah belajar oleh pusdatin Kemendikbud, TV edukasi Kemendikbud, tatap muka daring program sapa duta rumah belajar Pusdatin Kemendikbud, LMS SIAJAR oleh SEAMOLEC Kemendikbud, aplikasi daring untuk paket A, B, C, guru berbagi, membaca digital, video pembelajaran, suara edukasi Kemendikbud, radio edukasi Kemendikbud, buku sekolah elektronik, mobile edukasi bahan ajar multimedia, modul pendidikan kesetaraan, sumber bahan ajar peserta didik SD, SMP, SMA, dan SMK. Sumber dan media yang mendukung dalam pelaksanaan PJJ secara luring menurut Dinas Pendidikan dan Kebudayaan Kabupaten Cilacap (2020) yang menyatakan bahwa pembelajaran di rumah secara luring dalam masa belajar dari rumah dapat dilaksanakan melalui: a) televisi, contohnya program belajar dari rumah melalui TVRI, (b radio, c) modul belajar mandiri dan lembar kerja, d) bahan ajar cetak, dan e) alat peraga dan media belajar dari benda dan lingkungan sekitar.

Kelebihan pembelajaran jarak jauh menurut Rusman (Daryanto, 2017: 101) yaitu pertama tersedianya fasilitas emoderating di mana pendidik dan peserta didik dapat berkomunikasi secara mudah melalui fasilitas internet tanpa dibatasi oleh jarak, tempat, dan waktu. Kedua peserta didik dapat belajar atau mereview bahan pelajaran setiap saat dan di mana saja jika diperlukan. Ketiga apabila peserta didik memerlukan tambahan informasi yang berkaitan dengan bahan yang dipelajari, ia dapat melakukan akses di internet secara mudah. Keempat pendidik maupun peserta didik dapat melakukan diskusi melalui internet yang dapat diikuti dengan jumlah peserta yang banyak, sehingga menambah ilmu pengetahuan dan wawasan yang lebih luas.

Pembelajaran jarak jauh tidak hanya memiliki kelebihan, disisi lain juga tidak terlepas dari berbagai kekurangan yang dihadapinya. Kekurangan pembelajaran jarak jauh yang dinyatakan Rusman (Daryanto, 2017: 102) antara lain kurangnya interaksi antara pendidik dan peserta didik atau bahkan antar sesama peserta didik yang dapat memperlambat values dalam proses pembelajaran, peserta didik yang tidak mempunyai motivasi belajar yang tinggi cenderung gagal.

PJJ dilaksanakan dengan menggunakan Sistem Pengelolaan Pembelajaran yang meliputi proses administrasi, perencanaan pembelajaran, pelaksanaan pembelajaran, penilaian hasil belajar, dan pengawasan pembelajaran. Adapun kebijakan PJJ yang ditetapkan oleh Kemendikbud (2014: 7) yang berisi 
tentang pelaksanaan pembelajaran sebagaimana dimaksud pada ayat (1) meliputi belajar mandiri dengan memanfaatkan berbagai sumber belajar, tutorial dan responsi dengan berbagai sarana komunikasi dan penugasan, pengumpulan, serta penilaian tugas baik secara online maupun offline. Latihan dan ujian dengan memanfaatkan beragam jenis dan alat penilaian, penilaian beragam kegiatan belajar, praktikum dengan menggunakan perangkat lunak simulator atau laboratorium kering (dry lab).

Berdasarkan hasil wawancara dengan Kepala Sekolah SD Negeri Karangrena 03, menyatakan bahwa pada saat kondisi sekarang ini dengan adanya pandemi Covid-19 SD Negeri Karangrena 03 melaksanakan pembelajaran jarak jauh terhadap peserta didik mulai dari kelas I sampai dengan kelas VI. Hal tersebut diperkuat dengan adanya surat edaran dari Kepala Dinas Pendidikan dan Kebudayaan Kabupaten Cilacap No. 471 (2020: 1) yang menyatakan bahwa "Pelaksanaan kegiatan belajar mengajar di rumah bagi peserta didik PAUD Formal dan Non formal, SD dan SMP Negeri/ Swasta". Kepala sekolah memutuskan untuk menerapkan sistem daring (dalam jaringan) dan luring (luar jaringan). Pelaksanaan PJJ tentu saja harus ada peran orang tua sebagai pengganti guru di rumah untuk mendampingi putraputrinya belajar dari rumah.

Berdasarkah hal di atas, peneliti tertarik melakukan penelitian di SD Negeri Karangrena 03 dengan memfokuskan penelitian pada pelaksanaan pembelajaran jarak jauh di sekolah dasar, serta faktor pendukung dan penghambat dari pelaksanaan pembelajaran jarak jauh.

\section{METODE}

Metode penelitian ini menggunakan kualitatif deskriptif. Penelitian kualitatif ini digunakan peneliti untuk menggali informasi lebih mendalam, sehingga dapat memperoleh data yang lebih lengkap dan bermakna dari responden. Peneliti mengumpulkan informasi menggunakan berbagai prosedur pengumpulan data berdasarkan waktu yang sudah ditentukan.

Penelitian ini dilakukan di SD Negeri Karangrena 03 yang terletak di jalan Rajawali Rt 3/ Rw 2, Desa Karangrena, Kecamatan Maos, Kabupaten Cilacap. Waktu penelitian dilaksanakan pada bulan April - Juli tahun 2020.

Partisipan dalam penelitian ini adalah kepala sekolah, guru kelas II dan kelas VI, serta perwakilan orang tua. Pemilihan partisipan dalam penelitian ini karena mampu membantu dalam memperoleh data dan informasi.

Instrumen penelitian merupakan hal yang penting dalam penelitian karena untuk memperoleh data yang diperlukan. Instrumen dalam penelitian kualitatif merupakan peneliti itu sendiri dengan berbagai kegiatan yang mendukung peneliti melakukan penelitian seperti dokumentasi, observasi, atau wawancara dengan para partisipan.

Teknik pengumpulan data dalam penelitian digunakan untuk memperoleh data. Teknik pengumpulan data yang digunakan dalam penelitian ini antara lain observasi, wawancara dan dokumentasi.

Analisis data yang digunakan oleh peneliti adalah analisis data kualitatif. 


\section{JRPD (Jurnal Riset Pendidikan Dasar)}

Jurnal Riset

Pendidikan Dasar

Penelitian ini menggunakan analisis data model Miles dan Huberman. Penelitian kualitatif dalam menyajikan data yang paling sering digunakan adalah dengan teks yang bersifat naratif. Terdapat tiga tahap dalam analisis data yaitu data reduction (reduksi data), data display (penyajian data), dan conclusion drawing/ verification. Ketiganya saling berkaitan satu dengan yang lain, peneliti sebagai human instrument berada di antara ketiga kegiatan analisis data tersebut.

Uji keabsahan data yang dilaksanakan dalam penelitian ini menggunakan triangulasi. Peneliti yang melakukan pengumpulan data dengan triangulasi, maka sebenarnya peneliti melakukan data yang sekaligus menguji kredibilitas data yaitu mengecek kredibilitas data dengan berbagai teknik pengumpulan data dan berbagai sumber data. Peneliti menggunakan dua jenis triangulasi yaitu triangulasi teknik dan triangulasi sumber.

\section{HASIL PENELITIAN}

Penelitian didahului dengan melakukan observasi langsung ke sekolah yaitu SDN Karangrena 03. Peneliti langsung bertemu dengan Kepala Sekolah dan memperbincangkan tentang pelaksanaan PJJ yang dilakukan oleh sekolah. Berdasarkan wawancara yang di peroleh bahwa sekolah sudah melaksanakan PJJ. Pihak sekolah melaksanakan rencana PJJ secara fleksibel dengan melihat keadaan dan kondisi peserta didik. Hal ini sesuai dengan pernyataan dari Latip (Huang, 2020: 109) terkait pembelajaran secara Flexsible Learning. Guru ikut serta melakukan perencanaan sesuai dengan keadaan, dan situasi dengan tujuan memberikan hasil belajar pada peserta didik secara maksimal.
Pihak sekolah mendukung strategi apa yang akan digunakan oleh guru dalam mengajar. Guru memanfaatkan fasilitas pembelajaran dengan menerapkan strategi pembelajaran teknologi, memudahkan peserta didik untuk menerima materi dari guru, sehingga pembelajaran dapat tersampaikan.

SE Dinas Pendidikan dan Kebudayaan Kabupaten Cilacap (2020) menyatakan bahwa dilaksanakan menggunakan PJJ yang dibagi ke dalam dua pendekatan: 1) PJJ dalam jaringan (daring), 2) PJJ luar jaringan (luring). SDN Karangrena 03 telah mengikuti aturan yanng di keluarka oleh SE Dinas Pendidikan dan Kebudayaan Cilacap dengan menerapkan metode pembelajaran daring dan luring. Pembelajaran daring guru selalu menggunakan whatsapp group untuk memberikan presensi pada peserta didik serta mengirimkan tugas dan materi. Pembelajaran luring dilaksanakan sebagai pembelajaran tambahan yaitu dengan guru membagi kelompok belajar sehingga guru dapat door to door mendatangi peserta didik. Hal ini bertujuan agar peserta didik semangat dalam proses pembelajaran.

Guru di SDN Karangrena 03 menggunakan model PJJ dengan memberikan materi secara online pada peserta didik kemudian di download dan dipelajari secara manual (offline), selain itu guru memberikan materi ppembelajaran secara online dan peserta didik mempelajari secara online. Sesuai dengan model PJJ menurut Aziz (2019: 309) menyatakan bahwa model pembelajaran era digital terdiri 3 model yang pertama, guru memberikan materi pembelajaran secara online pada peserta didik kemudian 
di download dan dipelajari secara manual (offline), kedua guru memberikan materi pembelajaran secara online dan peserta didik mempelajari secara online juga, dan ketiga kolaborasi antara pembelajaran yang berlangsung antara online dengan offline. Sumber dan media yang digunakan di SD Negeri Karangrena 03 dengan dukungan dari pihak sekolah yaitu menggunakan gadget, serta memanfatkan fasilitas dari pemerintah terkait dengan berbagai macam aplikasi untuk belajar.

Evaluasi terhadap pelaksanaan PJJ bahwa masih terdapat berbagai kelemahan diantaranya orang tua masih kesulitan untuk menjadi pengganti guru sebagai fasilitator pada saat pendampingan proses belajar, karena terdapat orang tua yang kurang memahami materi tersebut. Perlu adanya perbaikan lagi agar mencapai hasil yang maksimal.

Faktor pendukung yang ditemukan dalam pelaksanaan PJJ di SD Negeri Karangrena 03 yang pertama yaitu guru mempersiapkan perencanaan yang matang dalam melaksanakan PJJ, karena guru berperan penting dalam pelaksanaan PJJ. Faktor pendukung yang kedua yaitu dari pihak sekolah memberikan bantuan berupa subsidi kuota internet untuk meringankan beban orang tua, sehingga PJJ dapat dilaksanakan dengan lancar. Ketiga guru dan orang tua dapat memanfaatkan teknologi dan komunikasi untuk saling berinteraksi tanpa adanya kendala waktu, karena dapat dilakukan kapan saja dan dimana saja. Sependapat dengan Latip (2020: 109) yang menyatakan bahwa faktor penentu keberhasilan PJJ adalah teknologi yang merupakan media, alat dan sarana penunjang terjadinya proses interaksi antara pengajar dan pembelajar.

Faktor penghambat pelaksanaan PJJ yang pertama yaitu sebagian orang tua yang memiliki pekerjaan tetap, tidak bisa selalu mendampingi peserta didik dalam kegiatan PJJ, karena memiliki tugas dan tanggung jawab dalam pekerjaannya. Kedua yaitu orang tua memerlukan penjelasan lebih terkait dengan tugas yang diberikan kepada peserta didik. Ketiga yaitu motivasi belajar peserta didik menjadi menurun karena kurang pendampingan dari orang tua, dan tidak belajar secara langsung dengan guru. Sesuai pernyataan oleh Dewi (2020: 61) yang menyatakan bahwa faktor penghambat pembelajaran jarak jauh diantaranya yaitu pekerjaan orang tua

Pihak sekolah melaksanakan upaya-upaya untuk mengatasi hambatan PJJ diantaranya guru dapat menggunakan teknologi untuk melangsungkan proses pembelajaran dengan memanfaatkan kecanggihan teknologi sesuai kebutuhan materi pembelajaran dan mempermudah guru dalam proses pembelajaran. PJJ menggunakan dua cara yaitu pembelajaran daring dan pembelajaran luring. Kedua pembelajaran ini harus diinovasikan oleh guru sehingga proses pelaksanaan PJJ dapat berjalan dengan baik dan sesuai dengan tujuan pembelajaran. Kepala sekolah dan guru juga selalu memberi motivasi agar pelaksanaan PJJ dapat berjalan, dengan itu harus ada dukungan dari orangtua peserta didik. 


\section{JRPD (Jurnal Riset Pendidikan Dasar)}

\section{SIMPULAN}

Merujuk pada temuan penelitian yang telah diuraikan di atas, dapat dirumuskan beberapa simpulan penelitian yaitu Pelaksanaan PJJ di SDN Karangrena 03 menggunakan metode pembelajaran daring dan luring, strategi yang digunakan guru yaitu menggunakan teknologi berbantu media aplikasi Whatsapp group. Faktor pendukung PJJ diantaranya guru mempersiapkan perencanaan yang matang dalam pelaksanaan PJJ, adanya dukungan fasilitas internet dari sekolah, dan guru serta orang tua dapat memanfaatkan teknologi untuk komunikasi tanpa adanya kendala waktu.

Faktor penghambat PJJ yaitu sebagian besar orang tua tidak bisa selalu mendampingi peserta didik dalam belajar karena memiliki pekerjaan yang tidak bisa ditinggalkan. Tugas yang diberikan guru memerlukan penjelasan lebih, dikarenakan orang tua kurang menguasai materi yang diberikan oleh guru, dan motivasi belajar pada peserta didik menjadi menurun. Berdasarkan faktor penghambat pihak sekolah mengupayakan cara untuk mengatasi hambatan PJJ diantaranya yaitu guru dapat menggunakan teknologi untuk melangsungkan proses pembelajaran dengan memanfaatkan kecanggihan teknologi sesuai kebutuhan materi pembelajaran dan mempermudah guru dalam proses pembelajaran. PJJ menggunakan dua cara yaitu pembelajaran daring dan pembelajaran luring. Kedua pembelajaran ini harus diinovasikan oleh guru, sehingga proses pelaksanaan PJJ dapat berjalan dengan baik dan sesuai dengan tujuan pembelajaran. Kepala sekolah dan guru juga selalu memberi motivasi agar pelaksanaan PJJ dapat berjalan, dengan itu harus ada dukungan dari orangtua peserta didik.

\section{DAFTAR PUSTAKA}

Azis, T. N. (2019). Strategi Pembelajaran Era Digital. Annual Conference on Islamic Education and Social Sains, 1(2): 308-318.

Daryanto \& S. Karim. (2017). Pembelajaran Abad 21. Yogyakarta: Gava Media.

Dewi, M. (2020). Analisis Kerja Sama Guru dengan Orang Tua dalam Pembelajaran Online di Era Covid 19 di MI Azizan Palembang. Jurnal Edukasi Madrasah Ibtidaiyah, 2(2), 54-64.

Dinas P dan K. (2020). Surat Edaran dari Kepala Dinas Pendidikan dan Kebudayaan Kabupaten Cilacap No. 471 tahun 2020 tentang Pelaksanaan Kegiatan Belajar Mengajar di Rumah bagi Siswa PAUD Formal dan Nonformal, SD dan SMP Negeril Swasta. Cilacap. Dinas Pendidikan dan Kebudayaan.

Dinas P dan K. (2020). Surat Edaran No. 443 Tentang Kegiatan Belajar dari Rumah dan Penerimaan Rapor Peserta Didik Tahun Pembelajaran 2019/2020 pada Satuan Pendidikan SD dan SMP Kabupaten Cilacap. Dinas Pendidikan dan Kebudayaan.

Kemendikbud. (2014). Peraturan Menteri Pendidikan dan Kebudayaan Republik Indonesia No. 119 Tahun 2014 tentang Penyelenggaraan Pendidikan Jarak Jauh Jenjang Pendidikan Dasar dan Menengah. Menteri Pendidikan dan Kebudayaan. 
Kemendikbud. (2020). Surat Edaran Nomor 15 Tahun 2020 Tentang Pedoman Penyelenggaraan Belajar Dari Rumah dalam Masa Darurat Penyebaran Corona Yirus D/Sease (Covid-19). Kementriann Pendidikan dan Kebudayaan.

Latip, A. (2020). Peran Literasi Teknologi Informasi dan Komunikasi pada Pembelajaran Jarak Jauh di Masa Pandemi Covid-19. Jurnal Edukasi dan Teknologi Pembelajaran, 1(2), 107-115.

Setiawan, A. R. (2020). Lembar Kegiatan Literasi Saintifik untuk Pembelajaran Jarak Jauh Topik Penyakit Coronavirus 2019 (COVID-19). Jurnal Edukatif, 2(1), 28-37.

Teguh, M. (2015). Difusi Inovasi dalam Program Pembelajaran Jarak jauh di Yayasan Trampil Indonesia. Jurnal Scriptura, 5(2), 1-18.

Yerusalem, M. R., A. F. Rochim., K. T. Martono. (2015). Desain dan Implementasi Sistem Pembelajaran Jarak Jauh di Program Studi Sistem Komputer. Jurnal Teknologi dan Sistem Komputer, 3(4), 481-492. 